\title{
The isolated locality of Zodarion rubidum Simon, 1914 (Araneae: Zodariidae) in Poland
}

\author{
Robert RozWAŁKA and Rafał GosiK
}

\begin{abstract}
Department of Zoology, Institute of Biology and Earth Sciences of Maria Curie-Sklodowska University,
\end{abstract} Akademicka 19,20-033 Lublin, Poland; e-mail: rrozwalk@biotop.umcs.lublin.pl; e-mail: rgosik@op.pl

\begin{abstract}
The paper contains the description of a new isolated locality of Zodarion rubidum Sim. in the eastern part of Poland. The diagnostic features of the species are presented in the drawings based on the collected specimen. The circumstances of the spreading of the species are discussed.
\end{abstract}

Key words: Zodarion rubidum, distribution, Poland

\section{INTRODUCTION}

Zodarion rubidum Simon is a spider originating from south-western France (Bosmans 1994, 1997, Pekár \& Král 2002). The process of expeditious spreading of the species in the northern and eastern directions has been observed since the 1980s. For the first time outside France, it was reported in central Europe in Berlin (Broen 1986, Broen \& Moritz 1987). The species was soon found also in Austria (Thaler \& Noflatscher 1989), the Czech Republic (Buchar et al. 1995), Slovakia (Pekar 1994) and Hungary (Tóth et al. 1996). In 1996 Z. rubidum was reported for the first time from Poland, namely from Wrocław in the southwestern part of the country (Woźny \& Siwek 1996). The locality was situated exactly at the border of the area of the known distribution of the mentioned spider (Bosmans 1997, Pekár \& Král 2002). However, the new record of this species from the Bug River valley situated in south-eastern Poland (more than $400 \mathrm{~km}$ from other known localities) is rather surprising.

The morphological descriptions of mentioned species given by (Bosmans 1997, Nentwig et al. 2003, Thaler \& Noflatscher 1989, Woźny \& Siwek 1996) seem to be not always accurate and sufficient. On account of this fact it is utterly important to give a detailed description of the found specimens of Zodarion rubidum in this paper.

\section{EXAMINED MATERIAL AND LOCALITY}

Zodarion rubidum 1 §; leg. R. Gosik; det. et coll. R. Rozwałka. The specimen comes from the material caught in Barber traps 8.05-4.06.2002 in Gródek at the Bug River $\left(50^{\circ} 49^{\prime} \mathrm{N}, 23^{\circ}\right.$ 57’ E) [UTM GB 03]: (Fig. 1).

Zodarion rubidum was collected in xerothermic fallow with loess soil that was periodically used as extensive pasture. The vegetation of adjacent areas has a character of mosaic composition with dominant Calamagrostis epigeios and loose grasslands with Hieracium pilosella, Aster amellus, Thymus spp., Melampyrum spp. Brachypodium pinnatum, Agropyron spp. and other xerophilic plants. The following species were collected in the same sample: Ceratinella brevis (Wid.) - 1へ, Alopecosa accentuata (Latr.) - 2 +, A. pulverulenta (Cl.) - $5 \hat{\jmath}, 1$ + , Aulonia albimana (Walck.) $-8 \hat{\jmath}$, Pardosa lugubris (Walck.) $-5 \hat{\jmath}$, Trochosa ruricola (de Geer) $-1 \hat{\jmath}$, 


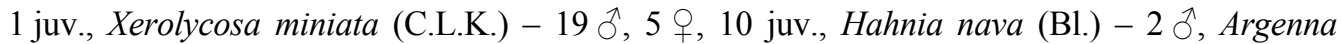
subnigra (O.P.-C.) - $2 \hat{\jmath}$, Cheiracanthium campestre Lohm. - $1 \hat{\jmath}, 1$ + , Clubiona neglecta O.P.C. $-1 \hat{\jmath}$, Drassyllus pusillus (C.L.K.) $-6 \hat{\jmath}$, Haplodrassus signifer (C.L.K.) - $12 \hat{\jmath}$, Micaria pulicaria (Sund.) - 1 ㅇ, Zelotes electus (C.L.K.) - $6 \hat{\jmath}$, Ozyptila pullata (Th.) $-2 \hat{\jmath}, 1$ ㅇ, O. scabricula (Westr.) - $1 \hat{\jmath}, 2$ juv., Xysticus cristatus (Cl.) $-1 \hat{\partial}$, X. ulmi (Hahn) $-2 \hat{\jmath}$, Heliophanus flavipes (Hahn) $-1 \hat{\delta}$ and Sibianor aurocinctus (Ohl.) -1 q

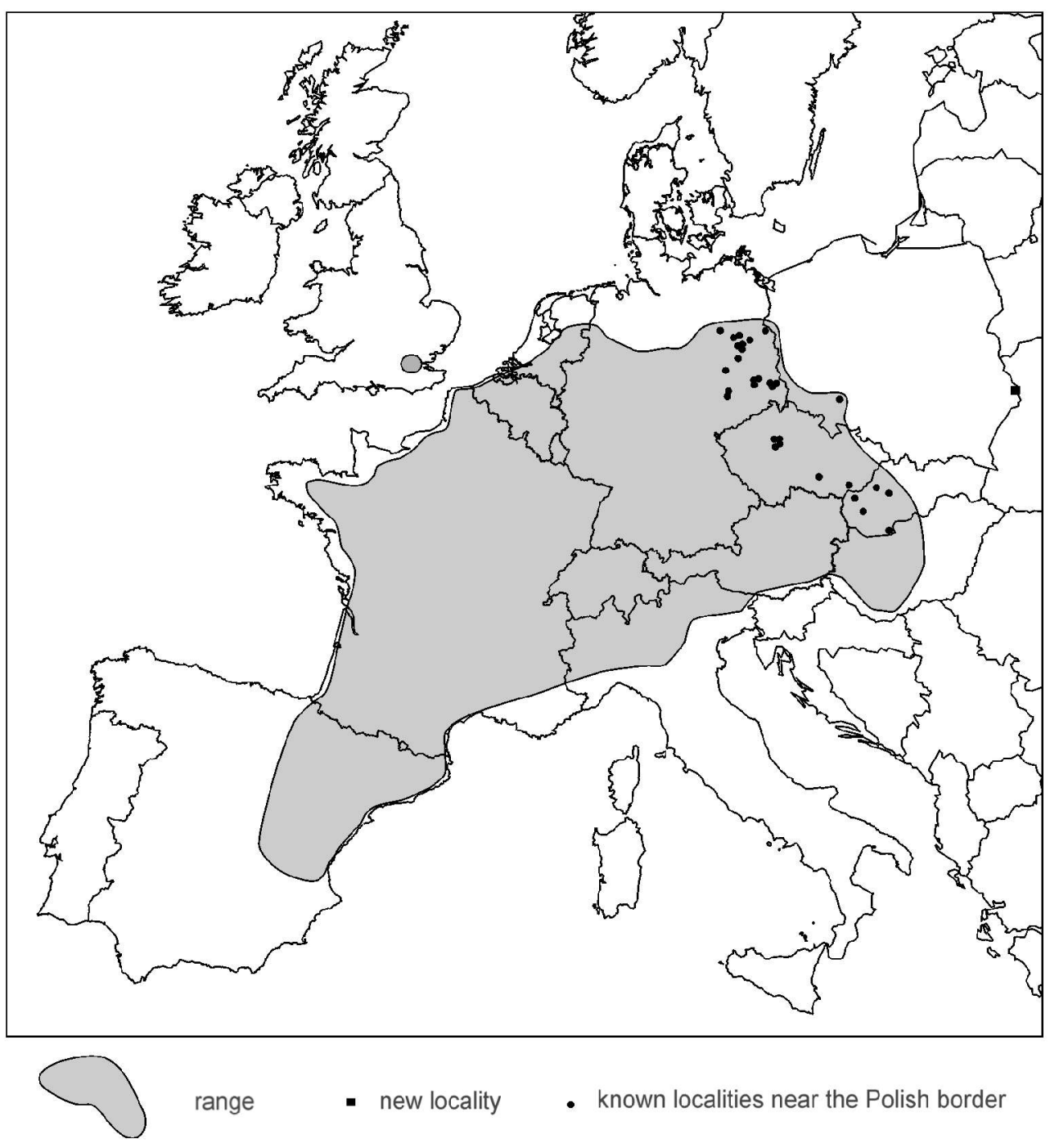

Fig. 1. Occurrence of Zodarion rubidium Sim. in Europe according to Bossmans 1997 and Pekar \& Kral 2002.

\section{DESCRIPTION OF THE SPECIMEN}

The total body length approximately $2.7 \mathrm{~mm}$. The dorsal part of the cephalothorax is orange-yellow with slightly darker edges and a brownish eye field. Chelicerae and sternum are brown-orange. The upper surface of the abdomen, and basis of spinnerets, is brown-red. 
Approximately one third of the flank surfaces of the body and abdomen are dirty white (=greyyellow-brown). The spinnerets are pale, light yellow. The coxa and the femur are orange, while the other segments are lighter and yellowish. Palps: a very massive retinaculum, highly sclerotized, hooked, embolus pointed (Fig. 2). The apex of the pedipalps with pronounced spike with four comb-like subapical spines underneath (Fig. 3). An explicit area of short setae on the dorsal part of the pedipals. The apical ending of the tibial apophysis is highly sclerotized and slightly curved (Fig. 4). In different descriptions and illustrations of copulatory organs of male Z. rubidum the distinctive features in respect of the number of thick comb-like subapical spines are given differently. Thaler \& Noflatscher (1989) and Woźny \& Siwek (1996) suggest that $Z$. rubidum is characterized by the presence of only three comb-like subapical spines. The collected specimen had four spines. Therefore, the results of our study confirm the description of Pekár (2002a) in which the number of subapical spines in Z. rubidum varies from three to five.
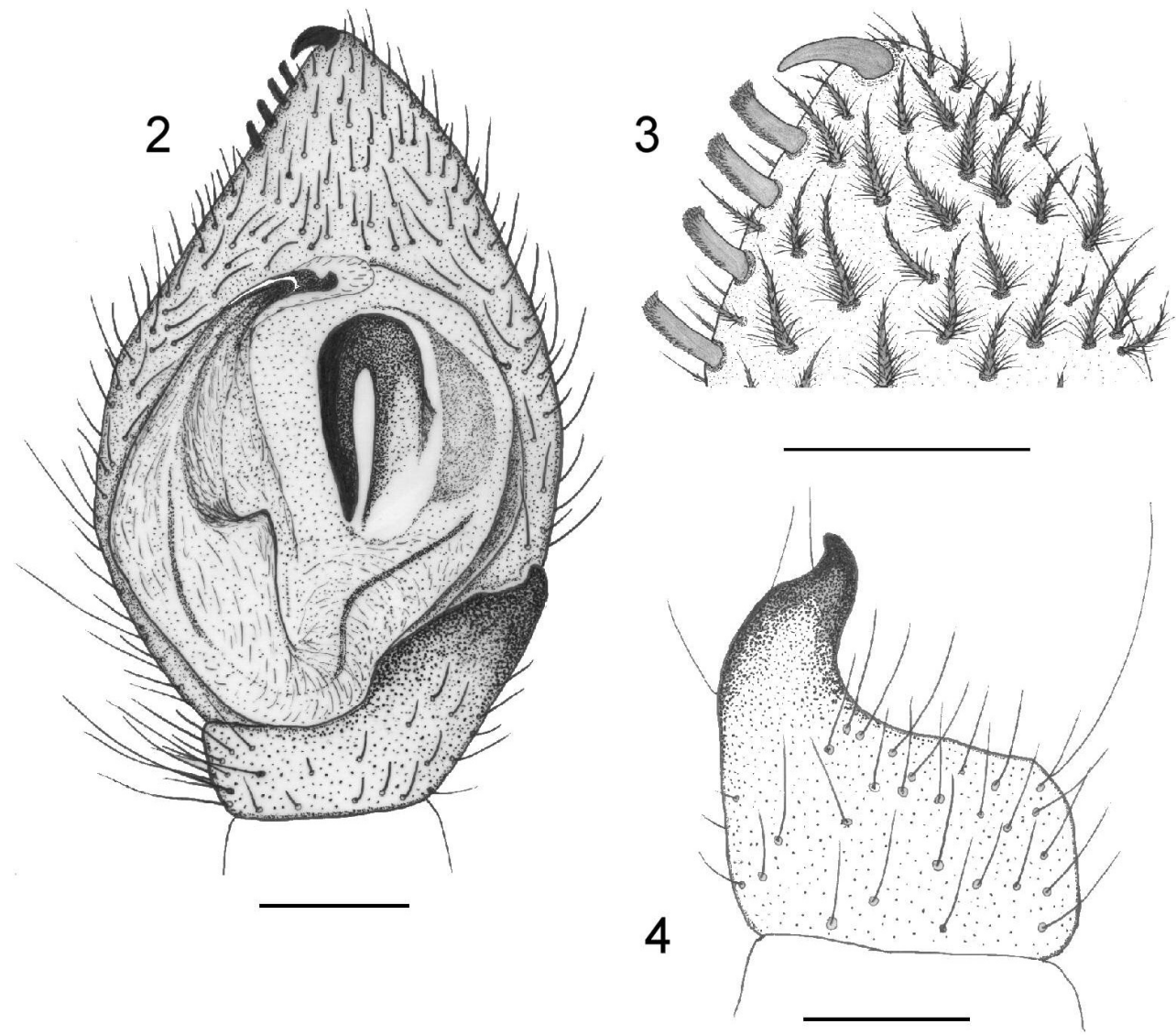

Figs 2-4. Zodarion rubidium Sim. 2 - male palp, ventral view, 3 - apical part of male palp 4 - tibial apohysis, lateral view. Scale bars $0.05 \mathrm{~mm}$.

\section{DISCUSSION}

Zodarion rubidum was reported in most of the Central European countries (Blick et al. 2004, Pekár \& Král 2002). It was also introduced into Great Britain (Harvey 1999) and the United States of America (Cushing \& Santangelo 2002, Vogel 1968). Z. rubidum is a 
xerophilous and myrmecophagous species (Pekár 2004, Pekár \& Král 2001, 2002). Red ants (e.g. Myrmica sabuleti) are considered the most important basis of aliment of the mentioned spider. In natural biotopes Z. rubidum was reported in sandy dunes and sandy or rocky xerothermic grasslands (Cushing \& Santangelo 2002, Leist 1994, Pekár 2002a). The numerous records of the species were observed in such habitats (Komposch \& Steinberger 1999, Leist 1994, Pekár 1997, 2002a). Z. rubidum can be regarded as a pioneer species in respect of its numerous occurrence in initial habitats like mine dumps and excavations. In anthropogenic environment it was collected mainly from mine waste dumps and excavations, quarries, sand pits, gravel mines (Krajča \& Krumpálová 1998, Pekár 1994, 1997, 2002a), insolated ruderal habitats (Pekár 2002a, Thaler 1993, Thaler \& Noflatscher 1989, Woźny \& Siwek 1996) and agrocenoses (Blick 1999, Jäger et al. 2000).

The places with anthropogenic genesis and also with mosaic composition of xerothermic grasslands similar to the found locality may by settled by many ecological groups of spiders like: xerophilic, thermophilic, agrobiontic or eurytopic. The accompanying arachnofauna indicated that the biotope of Z. rubidum had mainly xerothermic character (presence of Hahnia nava, Zelotes electus, Ozyptila pullata, O. scabricula). The new locality of Zodarion rubidum lies more than $400 \mathrm{~km}$ from other known localities of the species (Fig. 1). It confirmed that the species was not only very expansive but its dispersion and adaptive abilities were very high.

Many publications gave evidence to the hypothesis that the expansion of Z. rubidum was connected with human activity (Broen 1986, Komposch \& Steinberger 1999, Pekár 1997, 2002a, Thaler 1993, Thaler \& Noflatscher 1989). However, neither the precise connection nor the origin of new localities of the species was described. Broen \& Moritz (1987) reported that Z. rubidum was brought to Berlin with a railway transport of sand. Moreover, Pekár (2002b) suggested that rail transport of building materials (sand, gravel and stones), fossil materials and mine waste was the main expansion mode of the species in Europe. The locality of the species described in the paper was situated approximately 50-80 meters from railway tracks, which might confirm the similar origin of the locality.

However, we should also take into account another argument when we discuss the disperse abilities of Z. rubidum. Gravel and stone railway embankments and tracks with scanty vegetation were xerothermic habitats. Probably, Zodarion rubidum found suitable thermal and habitat conditions in the railway surroundings as well as a rich alimentary base in the form of ants. In this case, the net of railway embankments could act as a suitable migration track for the species. The occurrence of Atypus muralis Bert. (Rozwałka, unpublished data) in the environments also gave evidence to the hypothesis of migration along railway embankments, like other xero- and thermophilic species. For species with a low migration ability (small body size, absence of wings), the presence of alternative migration corridors (e.g. railway) is a principal agent in the colonization of new localities (Wanat \& Gosik 2003).

Bearing in mind the above reasons, we suppose that there is a possibility of finding more localities of the species, which lie not so far from the ranges of its occurrence, particularly in the southern part of Poland.

\section{REFERENCES}

BLICK T. 1999. Spinnen auf Kopfsalatfelder bei Kitzingen (Unterfranken, Bayern). Arachnologische Mitteilungen 17: 45-50. Blick T., Bosmans R., Buchar J., Gajdoš P., HÄngGi A., VAN Helsdingen P., RŮŽIČKa V., STARĘGA W. \& ThALER K. 2004. Checkliste der Spinnen Mitteleuropas. Checklist of the spiders of Central Europe. (Arachnida: Araneae). Version 1. Dezember 2004 - http://www.arages.de/checklist.html\#2004_Araneae

Bosmans R. 1994. Revision of the genus Zodarion Walckenaer, 1833 in the Iberian Peninsula and Balearic Islands (Araneae, Zodariidae). Eos 69: 115-142.

Bosmans R. 1997. Revision of the genus Zodarion Walckenaer, 1833, part II. Western and Central Europe, including Italy (Araneae: Zodariidae). Bulletin of the British Arachnological Society 10: 265-294. 
Broen B. 1986. Zur Kentnis der Spinnenfauna des Berliner Raumes. III. Spinnen auf dem Gelände des Tierparks Berlin (Araneae). Dtsche entomol. Z. 33: 283-292.

BROEN B. \& MORITZ M. 1987. Zum Vorkommen von Zodarion rubidum Simon, 1914, im Berliner Gebiet (Araneae, Zodariidae). Dtsche entomol. Z. 34: 155-159.

BUCHAR J., RƯŽIČKA V. \& KŮRKA A. 1995. Check list of spiders of the Czech Republic. In: RŮŽIČKA V. (ed.), Proc. $15^{\text {th }}$ Europ. Coll. Arachnol., České Budějovice 11-15 July 1994, pp. 35-53. Institute of Entomology, Czech Academy of Sciences, České Budějovice.

CUShING P. \& SANTANGElo R. 2002. Notes on the natural history and hunting behaviour of an ant eating zodariid spider (Arachnida: Araneae) in Colorado. J. Arachnology 30: 618-621.

HARVEY P. 1999. Zodarion rubidum SimON, 1914 (Araneae: Zodariidae), a spider new to Britain and Essex. Essex Naturalist 16: 29.

JÄger P. \& Staudt A., Schwarz B. \& Busse C. 2000. Spinnen (Arachnida: Araneae) von Weinbergen und Weinbergsbrachen am Mittelrhein (Rheinland-Pfalz: Boppard, Oberwesel). Arachnologische Mitteilung 19: 28-40.

Komposch Ch. \& Steinberger K. H. 1999. Rote Liste der Spinnen Kärntens. In: Holzinger W. E., Mildner P., ROTTENBURG T. \& WIESER C. (eds), Rote Listen gefährdeter Tiere Kärntens, Klagenfurt. Naturschutz in Kärnten 15: 567-618.

KRAJČA A. \& KRUMPÁlovÁ Z. 1998. Epigeic spiders (Araneae) communities of nickel leach dumps and their surroundings near Sered'. Biologia 53: 173-187.

LEIST N. 1994. Zur Spinnenfauna zweier Binnendünen um Sandhausen bei Heidelberg (Arachnida: Araneae). Beihefte zu den Veröffentlichungen der Landestelle für Naturschutz und Lanschaftspflege in Baden-Württemburg 80: 283-324.

PEKÁR J. 1997. Changes in epigeic spider community in primary succession on a brown-coal dump. Arachnologische Mitteilungen 14: 10-17.

PEKÁR S. 1994. The first record of Zodarion rubidum and Ostearius melanopygius for Slovakia (Arachnida: Araneae: Zodariidae, Linyphiidae). Entomol. Probl. 25: 97-100.

PEKÁR S. 2002a. Revision of the genus Zodarion (Araneae: Zodariidae) in the Czech and Slovak Republics. Acta Soc. Zool. Bohem. 66: 51-66.

PEKÁR S. 2002b. Zodarion rubidum SIMON, 1914: Railroad Riders? Newsletter of the British Arachnological Society 95: 11-12.

PeKÁR S. 2004. Predatory behavior of two European ant-eating spiders (Araneae: Zodariidae). J. Arachnology 32: 31-41.

PEKÁR, S. \& KRÁL J. 2001. A comparative study of the biology and karyotypes of two central European zodariid spiders (Araneae, Zodariidae). J. Arachnology 29: 345-353.

PEKÁR S. \& KRÁL J. 2002. Mimicry complex in two central European zodariid spiders (Araneae: Zodariidae): how Zodarion deceives ants. Biol. J. Linn. Soc. 75: 517-532.

THALER K. 1993. Beiträge zur Spinnenfauna von Nordtirol - 2: Orthognathae, cribellatae und haplogyne Familien, Pholcidae, Zodariidae, Mimetidae, sowie Argiopiformia (ohne Linyphiidae s.1.) (Arachnida: Araneida). Mit Bemerkungen zur Spinnenfauna der Ostalpen, Veröffentlichungen des Museum Ferdinandeum 73: 69-119.

THALER K. \& NoflatSCher M.-T. 1989. Neue und bemerkenswerte Spinnenfunde in Südtirol (Arachnida: Aranei). Veröffentlichungen des Museum Ferdinandeum 69: 169-190.

Tо́тн F., Kiss J., SAmU F., TóтH I. \& Kozma E. 1996. Az őszibúza fontosabb pókfajai (Araneae) talajcsapdas gyüjtésre alapozva (előzetes közlemény). Novényvédelem 32: 235-239.

WANAT M. \& GosiK R. 2003. Materiały do znajomości ryjkowców (Insecta: Coleoptera: Curulionoidea) doliny Bugu. Nowy Pamiętnik Fizjograficzny 2(1-2): 31-52.

Vogel B.R. 1968. A zodariid sopider from Pennsylvania (Araneida: Zodariidae). J. N. Y. Entomol. Soc. 96-100.

WoŹNY M. \& SIWEK P. 1996. Zodarion rubidum Simon (Aranei, Zodariidae) - nowy dla Polski gatunek pająka. Przegląd zoologiczny 40: 73-75.

\section{STRESZCZENIE}

\section{[Izolowane stanowisko Zodarion rubidum Simon, 1914 (Araneae: Zodariidae) w Polsce]}

Zodarion rubidum Sim. jest gatunkiem południowo-zachodnioeuropejskim, który od połowy lat 80-tych ubiegłego wieku rozpoczął ekspansję na obszary Europy Środkowej. W Polsce ten pająk był wykazany tylko z Wrocławia. Dotychczasowy zasięg jego występowania wskazywał, że ewentualnych dalszych stanowisk Z. rubidum można się było spodziewać przede wszystkim w południowo-zachodniej części kraju. Autorzy stwierdzili izolowane stanowisko tego gatunku nad Bugiem, oddalone o ponad $400 \mathrm{~km}$ od dotychczasowej wschodniej granicy zasięgu. 